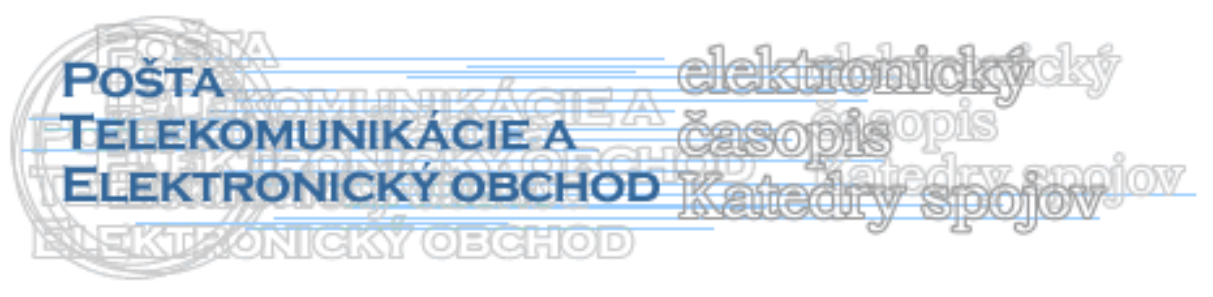

\title{
IMPLEMENTÁCIA STRATÉGIE SO SYSTÉMOM
}

\section{René Fučela* - Petra Kinzlová ${ }^{+}$}

V uplynulých rokoch boli zaznamenané zaujímavé pokroky v manažmente podnikov, ktoré implementovali metódu Balanced Scorecard prípadne iné metódy strategického manažmentu. Napriek týmto úspechom však stále existujú nedostatky v riadení podnikov, obzvlášt' v postupnej implementácii stratégie. Dozorné rady a vedenia spoločností majú spravidla dobré predstavy o tom, čo by sa v podniku malo dosiahnut' v najbližších rokoch. Tiež sa často stáva, že tieto predstavy ostávajú len na úrovni najvyššej úrovne riadenia vo forme vízií ako nerealizované napísané stratégie. To však nepostačuje ako základ pre strategickú komunikáciu. Úspešná implementácia stratégie si na jednej strane vyžaduje systematickú konkretizáciu ciel'ov a stratégií pre všetky ciele a úrovne podniku a na druhej strane tiež systematické plnenie krokov ciel'a nielen u operatívnych ciel'ov. To je vyriešené plnením finančných ciel'ov ako aj strategických ciel'ov, ktoré sú najčastejšie vyjadrené verbálnymi opismi želaných ciel’ov.

\section{Požiadavky na systém vedenia}

\section{a. úplný prístup}

Úplný prístup je jedným z najdôležitejších kritérií. Metódy, ktoré sa dajú obsiahnut' len čiastkovými oblast'ami vedenia a riadenia, nedokážu vyriešit' problém, aj ked' vedú v svojich čiastkových oblastiach k zlepšeniam. Obzvlášt' metódy, ktoré sa zaoberajú len meraním a vyhodnocovaním čísel, nepostačujú.

\section{b. integračný prístup}

Nové riadiace systémy vznikajú vel’mi zriedka na zelenej lúke. Doterajšie metódy manažmentu a systémy čísel musia byt' preto zmysluplne prepojené.

\section{c. motivačné komponenty}

L'udia chcú íst' vpred s podnikom. To sa darí najlepšie, ked' systém, ktorý sa zavádza, ponúka pre všetkých manažérov a pracovníkov prehl'adné výhody. O jednotlivých krokov sa musí hovorit' a už prvé kroky musia priniest' každému uživatel'ovi úspechy. Motivácia vzniká, pokial' stimulačný systém zohl'adňuje individuálny výkonnostný prínos zlepšenia procesov

\footnotetext{
* Ing. René Fučela, Žilinská univerzita v Žiline, Fakulta Prevádzky a ekonomiky dopravy a spojov, Katedra spojov, Univerzitná 1, 01026 Žilina, tel. č.: $041 / 513 \quad 3144$, fax: $041 / 5655$ 615, e-mail: rene.fucela@fpedas.utc.sk

+ Ing. Petra Kinzlová, Žilinská univerzita v Žiline, Fakulta Prevádzky a ekonomiky dopravy a spojov, Katedra spojov, Univerzitná 1, 01026 Žilina, tel. č.: $041 / 513$ 3145, fax: $041 / 5655$ 615, e-mail: petra.kinzlova@fpedas.utc.sk
} 
a pokial' sa neobmedzuje na finančné ciele, ktoré sú podriadené bilančnej politike. K tomu však patrí jasnost' ciel'ov a ich pochopitel'nost' ako aj jasne ohraničená zodpovednost' za ciele.

\section{d. počítačová podpora}

Komplexné úlohy sú l'ahšie dosiahnutel'né počítačovou podporou. Nikto dnes neakceptuje hŕby papierov. Dvojitej práci sa musí zabránit' a výsledky musia byt' k dispozícií rýchlo a všetkým oprávneným používatel’om.

\section{e. pragmatický a otvorený prístup}

Riadiaci systém musí byt' aplikovatel'ný postupne. L'udia sa nemenia zo dňa na deň. Organizácie potrebujú čas pre prispôsobenie sa. Musí byt' možné aj d'alšie rozšírenie bez toho, aby bolo nutné menit' metódu.

\section{f. premyslená metodika}

Ovládanie komplexnosti všetkých strategických elementov, možnost' zoskupovania a zhrňovania ciel'ov a postupov, pripravenost' pochopitel'ných metód pre kvalitatívne ciele, zapojenie a odsúhlasenie všetkých ciel'ov, ako aj strategických ako aj operatívnych a normatívnych ciel'ov sú dôležitými faktormi novej metodiky.

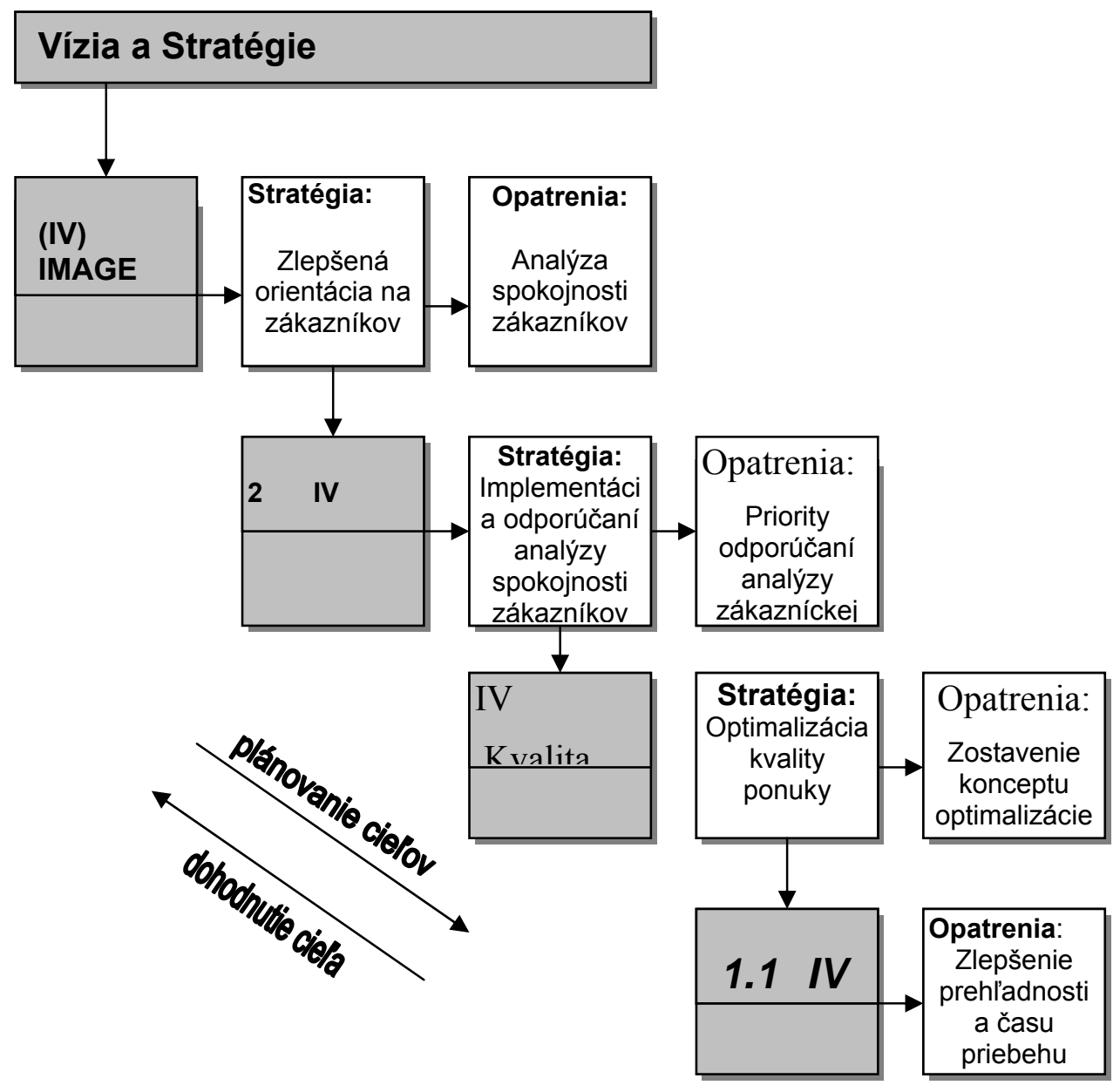

Obrázok 1: Príklad pre zakotvenie ciel’ov „stratégií a opatrení v ciel’ových kaskádach“ 


\section{g. organizačné prispôsobenie sa}

Organizačné štruktúry sú málokedy videálnom stave pre implementáciu stratégie a pre strategický kontroling. Najčastejšie sú ovplyvňované preferenciami riadiacich osôb posledných rokov. Z hl'adiska strategického vývoja je vhodnou cestou mapovanie existujúcich štruktúr, ktorý sa pretransformuje na vhodný model. Ďalší krok úspešného implementovania stratégie sa podarí len vtedy, pokial' sa zavedú skutočné zmeny v organizačnej štruktúre.

Jedným z problémov starých štruktúr je pokrývanie jednou osobou viacero rozličných úloh. Toto platí predovšetkým vúlohe l'udí zodpovedných za procesy. Pri prístupe orientovanom na ciele je hned' jasné, či sa dajú ciele týchto úloh navzájom zosúladit', alebo či si úplne odporujú. Pokial' by to bol tento prípad, tak by to viedlo k nevyriešitel'ným problémom. Riadiaca osoba musí svoju pozornost' venovat' rozličným osobám, stráca svoju energiu $v$ riešení týchto konfliktov a nachádza len nedostatočné kompromisy. Úloha zodpovedných osôb za procesy si vyžaduje myslenie v kontinuálnych zmenách procesu. Kreatívny dialóg vzniká, pokial' rôzne osoby zaujmú určité úlohy.

Implementácia stratégie je v jadre neustáleho presadzovania zmien v podniku. Celý podnik sa musí zmenit', aby sa dosiahli v podniku lepšie výsledky v zmysle stratégie. Aby došlo k týmto zmenám, musia vysielatelia impulzov a implementátori spolupracovat'. Iba ak prichádzajú neustále impulzy $\mathrm{z}$ vonku, od trhu, od zákazníkov a podnik ich príjme a implementuje, iba tak je možné, aby sa podnik d’alej rozvíjal.Vo väčšine podnikov nie sú úlohy vysielatel'ov impulzov a príjemcov impulzov rovnomerne zastúpení. Dynamické prostredie prináša tento model na svoje hranice. Každý impulz si vyžaduje koncepcionálnost' a tiež monitoring.

Postup projektov a opatrení v klasickej líniovej organizácii nie je úmyslom, ale výsledkom chýbajúceho času a energie v danej organizácii. Úloha vysielatel’ov impulzov vyžaduje intenzívne skúmanie do detailov. Na jednej strane je to trh a zákazníci a na druhej sú to procesy v podniku. Nestačí však len vypracovat' ciele a vyslovit' výzvy, ale tieto musia preniknút' a prebojovat' do celej organizácie prostredníctvom prispenia vedenia i každého zamestnanca v organizácii. Toto všetko si však vyžaduje dostatok zdrojov. Pri presnejšej analýza sa ukazuje, že spolupráca má jednu nevýhodu, že na jednej veci sa nepracuje koncentrovane dostatočne dlho. Toto vedie k neproduktívnosti, pretože sa stále opakuje zapracovávanie a to vždy vedie k rovnakej veci. Tento pílový efekt tvorí vo vel'a prípadoch až $30 \%$ ročného pracovného času procesných a projektových manažérov. Prispôsobené štruktúry organizácií a vedení sú predpokladom vytrvalej implementácie stratégie a sú častou „novej infraštruktúry“" pre ciel'ovo orientovaný systém riadenia.

\section{Kl’účové úlohy zmien}

Skúsenosti ukazujú, že väčšina podnikov neberie dostatočne vážne typické a dôležité úlohy obchodných trhov a procesov. Podstatnou úlohou l'udí zodpovedných za obchodné procesy je, aby zachytili impulzy od trhu a zákazníkov a tieto d’alej poskytli podniku, kde by mohli byt' d'alej implementované do procesov. Pritom sa musia venovat' implementácii s l'ud'mi zodpovednými za rozvoj organizácie a dohodnút's nimi d'alšie napredovanie, ktoré sa musí dodržovat'. S takýmto porozumením úloh spojené s vhodným obsadením pracovných pozícií, kde sú v súlade zodpovednost', povolanost' a kompetencie, je možné dosiahnut' potrebnú zmenu, ktorá je v podniku pevne zakotvená. Pre jednotlivé zmeny musia byt' určené zodpovedné osoby, pretože inak kontinuálne zlepšovanie procesov nie je možné. Z pohl'adu strategického kontrolingu pôsobí jasné stanovenie zodpovedností vel'mi pozitívne. Určenie 
l'udí zodpovedných za obchodné prostredie a procesy a ich podpora prostredníctvom vedenia je dôležitou súčast’ou „novej infraštruktúry“.

\section{Priradenie ciel'ov}

Konkrétne obsahy ciel'ov musia byt' zosúladené $\mathrm{s}$ jednotlivými úlohami a ich strategickými perspektívami. Matica vedenia musí zohl'adnit' vzor správania, ktoré vyplýva zo súhry úloh, stratégie a vlastníctva. Týmto sa dokáže prakticky zabránit' konfliktom ciel'ov. Strategické konflikty ako základ kreatívnych diskusií sa dokážu týmto cielene iniciovat'. $\mathrm{V}$ realite existuje $\mathrm{v}$ podniku vel'a divergentných ciel’ov. Jednou z podstatných výziev je, aby sa našla štruktúra, ktorá umožňuje v praxi zoskupovanie a zhrňovanie úloh pod zohl'adnením súvislostí spolupôsobenia. Vyhodnotenie jednotlivých ciel'ov podniku ukázalo, že všetky strategické ciele môžeme zaradit' do 5 základných kategórií:

1. Kompetencie: schopnosti a zručnosti...

2. Účinnost': transparencia výkonnostných procesov a zdrojov...

3. Rast. Vyčerpanie trhov...

4. Imidž: spokojnost' zákazníkov a zamestnancov, kvalita...

5. Nezávislost': bezpečie, riziko procesov...

K tomuto treba ešte pripočítat' nadradené projektové ciele. Klasifikácia ciel'ov do týchto kategórií a výstavba ciel'ových kaskád s nasledujúcim delením na oblasti a podnikové úrovne umožňuje vyvinút’ úplnú štruktúru pre strategické ciele. Táto komplexná štruktúra ponúka rámec pre konkrétnu štruktúru ciel'ov podniku. Týmto spôsobom sa vytvorí prehl'adná schéma pre všetky ciele pre jednotlivé úrovne podniku, na ktorých základoch je potom možné stavat' konkrétny systém ciel'ov podniku. Iba takáto jasná štruktúra umožňuje vytvorit' komplexnú súvislost' medzi príčinou a účinkom ciel'ov, stratégií a opatrení. V praxi sa v d’alšom kroku rozvíjajú ciel’ové kaskády základnej schémy, potom sa individuálne pre každý podnik prispôsobia a vyplnia podl’a individuálnych špecifík a okolností a tiež stratégií. Výhodou je tiež zredukovanie námahy a času pre jednotlivé efekty.

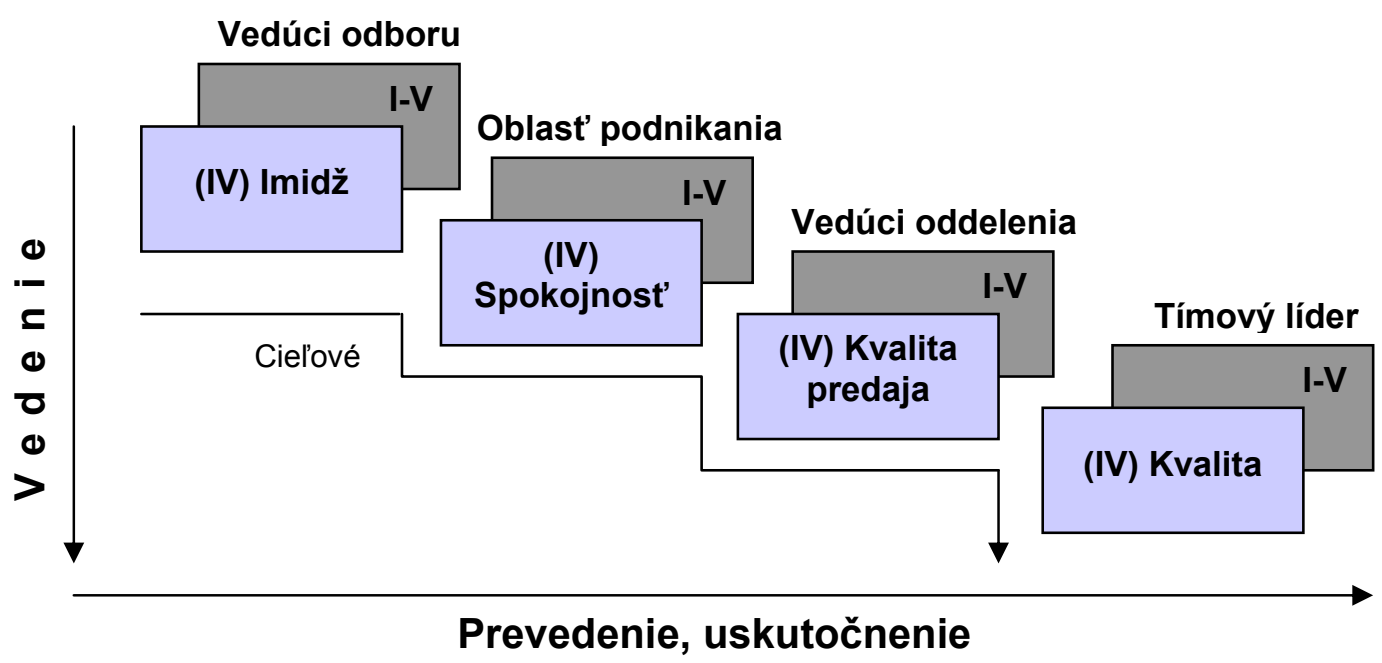

Obrázok 2: Schéma kaskády ciel’ov 


\section{Systematizácia ciel'ových typov}

Použitel'né údaje nám musia dávat' informácie o plnení ciel’ov, ako napríklad či výška obratu k určitému časovému bodu dosiahla stanovený ciel'. V rámci kontroly ciel'ov prostredníctvom zozbieraných údajov sa rozhoduje o neskorých a skorých indikátoroch. U skorých indikátorov sa vychádza z toho, že vývoj priamo alebo nepriamo ovplyvňuje neskoré indikátory. Klasickým príkladom je stav zákaziek, z vývoja ktorého dokážeme odvodit' predbežný vývoj obratu. Čo však ovplyvňuje skoré indikátory? Čo je treba dosiahnut', aby sa skoré indikátory vyvíjali podl'a želaní?

\section{Príčiny}

Najskôr je treba nájst' ovplyvňujúce faktory, ktorých stav a vývoj stále ovplyvňuje ciele. U ciel'ov môžeme rozlišovat' medzi operatívnymi a strategickými. Strategické ciele sú typickými zmenami stavov, operatívne ciele sú reprezentované finančnými ukazovatel'mi. Strategické ciele sa zaoberajú príčinami, operatívne ciele následkami. Tieto zmeny stavov sa nedajú merat' jednoduchými finančnými ukazovatel'mi. Stav predstavuje vo vel'a procesoch centrálnu príčinu pre chyby a náklady na reklamácie. Účinok sa musí merat finančne vtedy, ale stav ako ovplyvňujúci faktor úspechu sa nemôže merat' finančne. Príkladom môže byt' výpoved', že výroba plošných spojov je o 10tis eur čistejšia ako operačná sála a o 15tis eur čistejšia ako opravovňa áut. Tu existuje však jednoznačná súvislost' medzi hygienou na operačnej sále a kvótou úmrtnosti, čo sa dá dokázat'. Týmto môžeme povedat', že je definovatel'ný dobrý a zlý stav hygieny. Následne môžeme povedat', že zmena stavu A „,nehygienický“ na stav B „hygienický“ môžeme na základe kritérií objektívne vyhodnotit’ a tým aj merat'.

\section{Inovatívne meranie kvalitatívnych ciel'ov}

Ciel' musí najskôr opisovat' budúci žiadaný stav konkrétneho objektu. Pre každý ciel' potrebujeme východiskový stav resp. východiskovú hodnotu a ciel'ový stav resp. konečný stav a tiež časový bod, ku ktorému sa má ciel' dosiahnut'. Pre operatívne ciele, ktoré sa dajú merat' číslami, to nepredstavuje problém. Iné je to však pre strategické ciele, pre ktoré neexistujú strategické ciele. Tu je potreba nových inovatívnych metód, ktoré umožňujú meranie tiež kvalitatívnych ciel'ov. Toto sa dá dosiahnut' štruktúrovaným určením ciel'ových stavov a ciel'ových profilov.

V profile stavu sa musí opísat' osobný ciel' kompetencií zamestnancov prostredníctvom stavu ciel'ov. Pri zostrojovaní profilu stavov sa najskôr musí hl'adat' 3-5 najdôležitejších faktorov, ktoré ovplyvňujú kompetencie a charakterizuje ich stav v jednotlivých fázach. Väčšinou sa volia za časovú dimenziu štyri fázy a vyberie sa tri až pät' indikátorov. Prvá fáza opisuje prvé zlepšenia, druhá fáza ideálny stav. Jednotlivé indikátory môžu prispiet' s rozličnými váhami k celkovému vyhodnoteniu. Týmto dokážeme merat' „tradične nemeratel'né“ hodnoty, a tak dosiahneme dôležitý a inovatívny vývoj doterajších systémov.

\section{Získanie času na reakciu prostredníctvom predikcie}

Prostredníctvom profilov stavu sa darí merat' ovplyvňujúce faktory a príčiny pre vývoj skorých a neskorých indikátorov. Týmto sa umožní priame sledovanie jednotlivých krokov strategických ciel'ov úplne od začiatku. Zmeny v predikčných indikátoroch signalizujú neželený stav vývoja niekol'ko mesiacov až dva roky skôr. Týmto sa získa drahocenný čas. Systematický monitoring predikcií ponúka zmysluplné vysvetlenie a pomáha dostatočne skoro zaranžovat' korekcie. 


\section{Plánovanie a schval'ovanie ciel'ov}

Pre každé vedenie a pre každého pracovníka, ktorý je zapojený do systému ciel'ov, je $\mathrm{k}$ dispozícii sada stavových profilov, ktoré opisujú jeho strategické ciele pomocou stavových ciel'ov. Vízia a stratégia určujú nasmerovanie stavových ciel’ov. Pre každé t’ažisko ciel'a sa opisujú v stavovom profile kvalitatívne indikátory s konečnými stavmi vo viacerých fázach. Tieto slúžia ako podklad pre vyhodnotenie dosiahnutia ciel'ov. Jednota definovaných stavov ciel'a v podniku ukazuje na navzájom poprepájaný systém ciel'ov, ktorý je podkladom pre ciel'ovo orientovaný riadiaci systém, ktorý sa stará o to, že všetci zamestnanci majú konzistentné ciele a t’ahajú za jeden koniec.

\section{Top-Down-plánovanie a Bottom-Up-Commitment}

V plánovacom procese Top-Down sa zakotvujú ciele, stratégie a opatrenia ciel'ov. Týmto sa určujú ciel'ové hodnoty a plánovaný stupeň naplnenia k určitým termínom. Popritom sa určujú a terminujú patričné stratégie a opatrenia. Dohodnutie ciel'ov v procese Bottom-Up zabezpečuje Commitment pracovníkov a potvrdzuje uskutočnitel'nost' stratégie. V konkrétnom systéme riadenia podniku sú určené pre každú zapojenú osobu ciele, stratégie a opatrenia. Tiež je dôležité zvyšovanie imidžu značky, aby sa zlepšila spokojnost' zákazníckej skupiny. K tomu je medzi iným dôležité neustále zvyšovanie orientácie na zákazníkov. Analýza spokojnosti zákazníkov dáva impulzy, ako optimalizovat' kvalitu. Ciel'ovo orientovaný riadiaci systém podporuje plánovanie podnikových ciel'ov so stratégiou a opatreniami Top-Down a dohodnút' Bottom-Up. Prostredníctvom protiprúdovej metódy sa môže včas rozpoznat' uskutočnitel'nost' a prijatel'nost' stratégií a opatrení.

\section{Spiatočná väzba pokročenia $v$ ciel'och a prognózach}

Už krátko po zosumarizovaní ciel'ov riadiaceho systému je možné dostat' feedback k operatívnym a strategickým ciel'om. V pravidelnom sebahodnotení kvalitatívnych ciel'ov sa hodnotí aktuálny stav predikčných indikátorov. Prostredníctvom vizualizácie ciel'ov možno zistit' nezhody odhadov jednotlivých pracovníkov. U týchto spiatočných väzbách sa preväzuje skúsenosti s internými a externými faktormi pôsobenia so svojimi ciel'mi. Riadiaci systém s integrovaným ciel'ovo orientovaným manažmentom vedomostí umožňuje riadiace rozhodnutia na báze vedomostí, ktoré určujú informačnú kvalitu a pripravenost' nových opatrení. Každý riadiaci systém potrebuje zosumarizované dáta. Množstvo relevantných informácií sa konsolidujú a zhust’ujú. Kritické cesty by sa mali vizualizovat'. Ciele, stratégia, opatrenia a údaje sa systematicky zaznamenávajú. Strategické informácie sú ciel'ovo orientované a dajú sa kedykol'vek získat' $z$ databázy. Zosúladenie informácií prináša synergické efekty a umožňuje rýchly prístup k informáciám ako aj strategickým a operatívnym ciel'ov a tým zvyšuje stupeň dosažitelnosti ciel'ov.

\section{Záver}

Ciel'ovo orientovaný riadiaci systém d'aleko presahuje prístup Balanced Scorecard. Ukazuje metódy a nástroje, ktoré účinne podporujú implementáciu stratégie a strategický kontroling celostným a integratívnym prístupom. Pomocou cielovo orientovaného nasmerovania organizácie sa zabráni konfliktom ciel’ov a otvorí sa cesta energii pre nájdenie konštruktívnych riešení. 


\section{Literatúra}

[1] BRABANDER, E., Hilcher, I.:Balanced Scorecard - Stand der Umsetzung. Ergebnisse einer empirischen Studie, in: Controller Magazin, 26. Jg, 2001

[2] GÖTZE, U.: Szenatio-Technik in der strategischen Unternehmensplanung, Wiesbaden, 1993

[3] HORVÁTH\&PARTNER.: Balanced Scorecard umsetzen, Stuttgart, 2004

[4] ITTNER, D.,DAUGERT, J.: bereichs- und unternehmensbezogene Performancemaße zur Koordintion und Steuerung von Bereichsleitern, in Controling. Theorien und Konzeptionen, München, 2004

[5] KAPLAN, R., NORTON, D.: Balanced Scorecard - Strategien erfolgreich umsetzen, Stuttgart, 1997

[6] KAPLAN, R. NORTON, D.: Die strategie-fokussierte Organisation. Führen mit der Balanced Scorecard, Stuttgart, 2001

[7] MAYER, R., RIEGER, W.:Integriertes, wertorientiertes Profit-Center Management Unternehmensmodell und Managementinformationssystem als zentrale Steuerungsinstrumente, Controlling und financen, Stuttgart, 1999

[8] PORTER, M. E., What is strategy? In: Harvard Business Review, 1996

[9] REIß, M., Entnetzung, Erscheinungsformen und Erklärungsansätze, in: Stahk, H. K./von den Eichen, Vernetzte Unternehmen, Berlin, 2005

[10]WELGE., M.K., Al-Laham, A.: Strategisches Management, Grundlagen - Prozess Implementierung, Wiesbaden, 2003

\section{Grantová podpora}

Príspevok bol spracovaný v rámci projektu Pol'/SR/ŽU1/07 Moderné trendy strategického manažmentu a ich aplikácia $\mathrm{v}$ podniku ako faktor konkurencieschopnosti. 